\title{
MORBIDITY OF RHEUMATOID ARTHRITIS
}

BY

\author{
F. AMMITZBØL and E. SNORRASON \\ From the Medical Department C., Municipal Hospital of Bispebjerg, and the Public Health Insurance's \\ Physiatric Clinic, Copenhagen, Denmark
}

(RECEIVED FOR PUBLICATION APRIL 23, 1953)

For many years primary rheumatoid arthritis has been considered a progressive lesion. More recent studies of treatment with ACTH and cortisone have increased the interest taken in this disease, which is sometimes known to stop spontaneously while in an early stage (Hench, 1949).

Hitherto it has not been practicable to establish the incidence of spontaneous arrest with any degree of certainty (Snorrason, 1950). In investigating the morbidity of the lesion, one of our chief difficulties has been to obtain a sufficiently large amount of patient material controlled by the same criteria (preferably by the same examiner) for a long period.

Various studies have been published already, but either the groups of patients were not homogeneous (Fletcher, 1947; Steinbrocker, 1942; Metropolitan, 1931), or the authors concentrated on the relationship between rheumatism and occupation without examining the morbidity of the primary rheumatoid arthritis (Edstrøm, 1934; Snorrason, 1951).

In the Scandinavian countries, useful figures have been furnished by social institutions such as the Invalidity Court (Gram, 1942; Norgaard, 1946), and the National Health Service and practising physicians (Kalbak, 1947; Edstrøm, 1944; Heidemann, 1932; Schelde-Møller and Sylvest, 1946; Snorrason, 1951). Gram (1942) published an account of 1,014 cases from the Invalidity Court, among which he found a morbidity of 0.67 per thousand in the whole of Denmark for rheumatoid arthritis and chroni $\xi^{\prime}$ arthritis after rheumatic fever. Of these patients 866 were said to be suffering from rheumatoif arthritis, and the morbidity for this disease alone (Table I) was then 0.58 per thousand (corrected) Norgaard (1946), covering the patient material of the Invalidity Court for the year 1944 (a total of 1,932 applications for invalidity pension or sick benefit), found a morbidity of 0.30 per thousand. (Table I). The Swedish Ministry of Social Affairs (Højer and others, 1945) gave the number of cases of rheumatoid arthritis notified by all th\& physicians in Sweden as 16,004. This total in cluded all cases of "chronic peri-arthritis" and some cases of chronic arthritis after rheumatic fepero Thus the morbidity reached the strikingly high level of $2 \cdot 4$ per thousand (Table I).

\section{Material}

In the period 1943-1945 one of us (E.S.) had occasio to examine 533 rheumatoid arthritis patients who has been admitted in 1932-41 to the Medical Departments B. and C. of the Municipal Hospital of Bispebjer $\overrightarrow{\vec{g}}$ (Snorrason, 1950). Morbidity among these recent cases from the entire city of Copenhagen amounted to 1.5 per thousand; of these cases only 0.5 per thousand had nọp been treated previously (Table I).

From July, 1947, to June 30, 1952, moreover, the sams TABLE I

MORBIDITY OF FIVE GROUPS OF RHEUMATOID ARTHRITIS PATIENTS

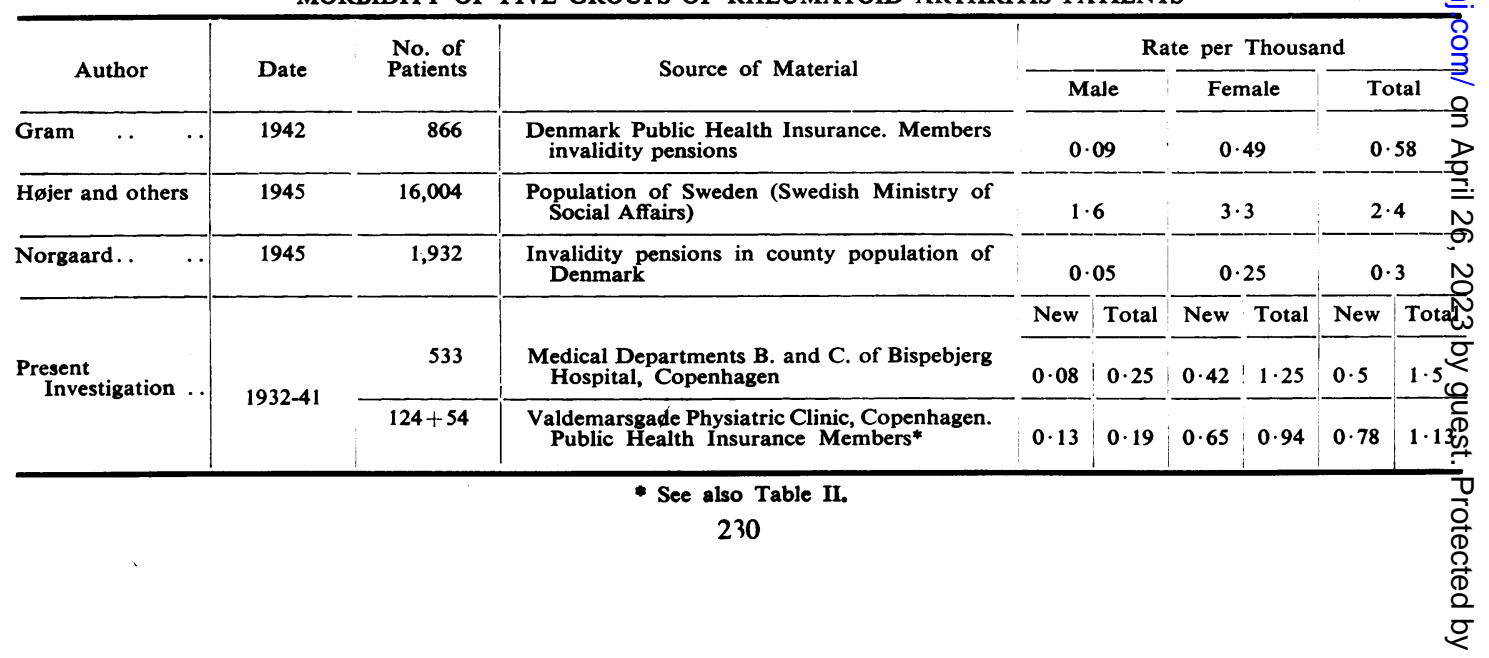


TABLE II

NUMBER OF NEW AND OLD (= PREVIOUSLY DIAGNOSED) CASES OF RHEUMATOID ARTHRITIS AMONG PUBLIC HEALTH INSURANCE PATIENTS

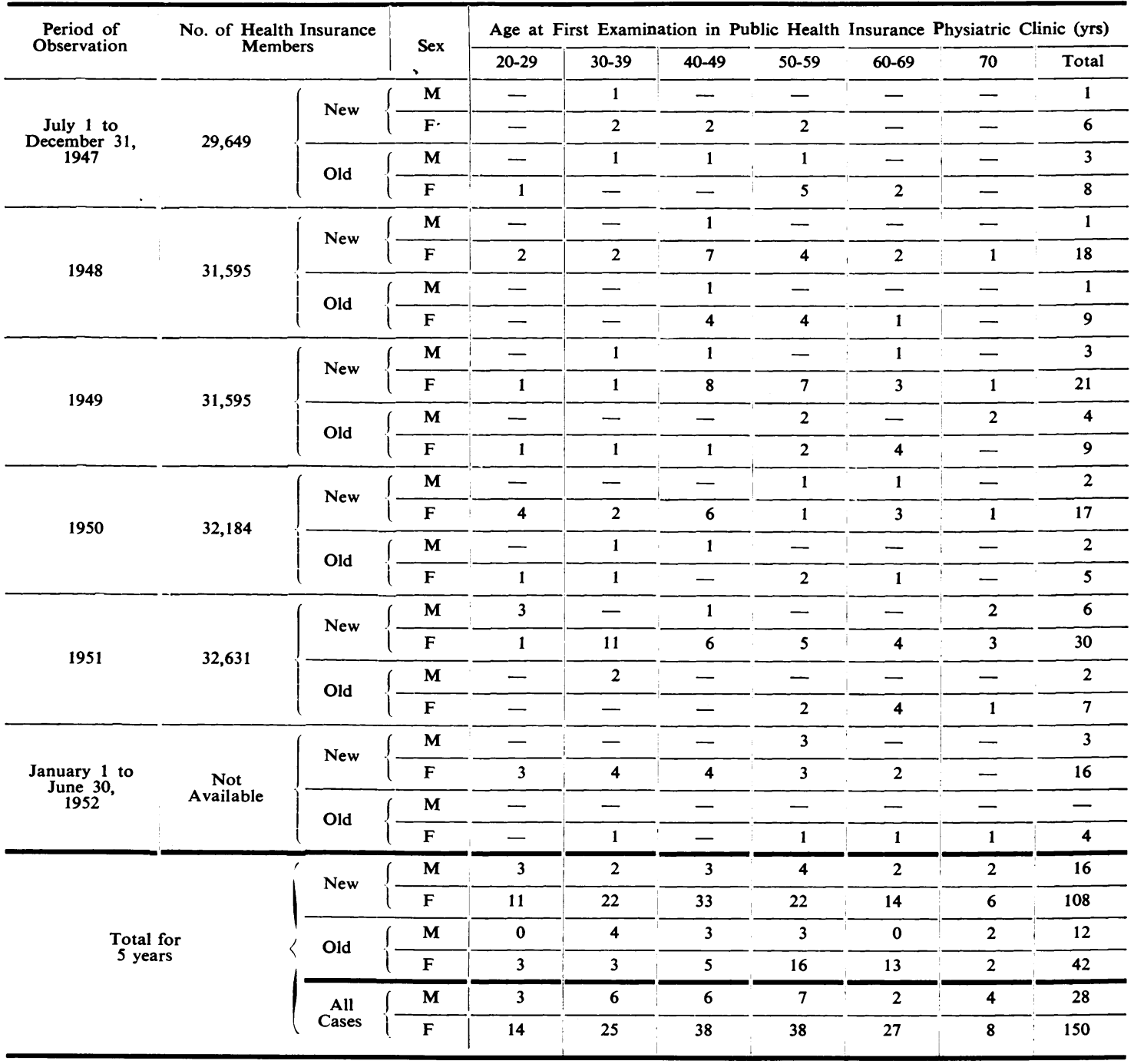

examiner personally investigated all ambulatory "new" (not previously diagnosed) cases referred to the Physiatric Clinic from a total of about 32,000 Public Health Insurance members. All the physicians who were treating the Public Health Insurance members in this district (Vanløse, Valby, and south-western Copenhagen), knowing that this investigation was being carried out, sent to the clinic all those patients who came into this category, suspected as well as undoubted cases. The distribution of this material by years and age groups is shown in Table II. The morbidity for the early cases was $0 \cdot 78$ per thousand, and the total $1 \cdot 13$ per thousand, presumably because the more severe cases were admitted to hospital, being unsuitable for ambulatory treatment.
The annual incidence of the disease is far from constant, presumably because of variations in the interest with which individual physicians referred such patients to our clinic. This factor may also be responsible for the apparent rise in morbidity towards the end of the period, but may not prove significant on continued observation.

\section{Results}

The difference in the morbidity figures for the early diagnosed cases in the Valdemarsgade Clinic and those for the previously untreated cases in the Bispebjerg Hospital affords no actual picture of the "reversibility" of primary rheumatoid arthritis, but is strongly suggestive of the existence of such a phenomenon (Hench, 
TABLE III

MORBIDITY FROM RHEUMATOID ARTHRITIS IN EIGHT HEALTH SERVICE DISTRICTS* OF COPENHAGEN IN RELATION TO NUMBER OF INHABITANTS AND DENSITY OF POPULATION

\begin{tabular}{|c|c|c|c|c|c|c|c|c|}
\hline \multirow{2}{*}{ District* } & \multicolumn{2}{|c|}{$\begin{array}{c}\text { Populationt } \\
\text { excluding Children }\end{array}$} & \multicolumn{2}{|c|}{$\begin{array}{l}\text { Density } \\
\text { per Hectare }\end{array}$} & \multicolumn{2}{|c|}{$\begin{array}{l}\text { Rheumatoid Arthritis } \\
\text { Patients, 1932-41 }\end{array}$} & \multicolumn{2}{|c|}{$\begin{array}{l}\text { Incidence of } R \text { heumatoid } \\
\text { Arthritis per Thousand }\end{array}$} \\
\hline & $\mathbf{M}$ & $\mathrm{F}$ & $\mathbf{M}$ & $F$ & $\mathbf{M}$ & $\mathrm{F}$ & $\mathbf{M}$ & $\mathrm{F}$ \\
\hline $\begin{array}{c}\text { I } \\
\text { II } \\
\text { III } \\
\text { IV } \\
\text { V } \\
\text { VI } \\
\text { VII } \\
\text { VIII }\end{array}$ & $\begin{array}{l}48,099 \\
36,021 \\
34,950 \\
26,867 \\
34,690 \\
26,556 \\
51,854 \\
49,322\end{array}$ & $\begin{array}{l}58,397 \\
45,981 \\
44,485 \\
30,584 \\
38,473 \\
29,036 \\
55,769 \\
33,887\end{array}$ & $\begin{array}{r}58 \\
62 \\
122 \\
99 \\
99 \\
22 \\
24 \\
76\end{array}$ & $\begin{array}{r}71 \\
79 \\
156 \\
113 \\
109 \\
25 \\
26 \\
88\end{array}$ & $\begin{array}{r}12 \\
12 \\
12 \\
10 \\
10 \\
6 \\
18 \\
7\end{array}$ & $\begin{array}{l}64 \\
61 \\
64 \\
51 \\
51 \\
30 \\
91 \\
34\end{array}$ & $\begin{array}{l}0 \cdot 25 \\
0 \cdot 33 \\
0 \cdot 35 \\
0 \cdot 39 \\
0 \cdot 26 \\
0 \cdot 23 \\
0 \cdot 35 \\
0 \cdot 14\end{array}$ & $\begin{array}{l}1 \cdot 09 \\
1 \cdot 11 \\
1.44 \\
1.66 \\
1.39 \\
1.03 \\
1.69 \\
0.63\end{array}$ \\
\hline Total & 308,359 & 356,612 & - & - & 87 & 446 & $0 \cdot 25$ & $1 \cdot 25$ \\
\hline
\end{tabular}

* Health Service districts in Copenhagen.

I: Inner City and Christianshavn:

II: Østerbro (Freeport quarter excluded);

III: Inner Nørrebro;

IV: Outer Nørrebro;

V: Vesterbro;

VI: Valby

VII: Brønshøj;

VIII: Amagerbro and Sundby.

+ On November 5, 1935.

1949; Snorrason, 1950). The idea finds support in an investigation of the distribution of the Bispebjerg patients in the eight health service districts of Copenhagen. Table III shows that during the period 1932-1941, altogether 533 patients suffering from rheumatoid arthritis were admitted to the Medical Departments B. and $C$. of the Bispebjerg Hospital. These 533 cases made up about one-fourth of the total number of cases of "polyarthritis" admitted to hospital in greater Copenhagen during this period. There is no relation between density of population and total morbidity rate.

It is also evident that the morbidity was equally distributed in all districts, and that the proportional figures for males and females were as generally stated: $1: 5$.

As the distribution of cases appears to be fairly uniform for the eight districts, it seems reasonable to calculate the morbidity on the basis of one Public Health Insurance district with about 32,000 members. This view is further corroborated by the fact that Gram (1942), Norgaard (1946), and Højer and others (1945) found that cases of rheumatoid arthritis were uniformly distributed in rural and urban districts.

\section{Summary}

The morbidity of rheumatoid arthritis may be reckoned as about $0 \cdot 8$ per thousand: that is, 3,000 to 4,000 of the 4 to 5 million inhabitants of Denmark are liable to be attacked by this disease each year.

Yet all these cases are progressive, necessitating hospitalization and social care (invalidity pension); in some cases the lesion appears to stop spontaneously. The number of such cases cannot be reckoned conclusively, but further control of the ambulatory patient material here reported (the Valdemarsgade patients) should make this possible. It is planned to re-examine the 124 early diagnosed cases after 5 years.

\section{REFERENCES}

Edstrom, G. (1934). Acta rheumatol., 6, 65

- (1944). Uppsala Läkarefor. Förh. Ny följd., 49, 303.

Fletcher, E. (1947). "Medical Disorders of the Locomotor System" Livingstone, Edinburgh. Pp. 98-119, by E. Lewis-Faning.
Gram, H. C. (1942). Ugeskr. Laeg., 94, 1069.

Heidemann, H. (1932). Ibid., 94, 587.

Hench, P. S. (1949). Proc. Mayo Clin., 24, 167. kande del III". Stockholm.

Kalbak, K. (1947). Dansk Gallup Institut "Landsundersøgelse af Gigtsygdomme i Danmark". Copenhagen.

Metropolitan Life Insurance Co. (1931). Statistical Bull., 12, No. 8, $\mathrm{C}$ p. 2 .

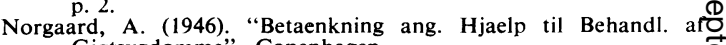
Gigtsygdomme;. Copenhagen.

Schelde-Møller, E., and Sylvest, O. (1946). "Rheumatiske Sygdommes samfundsmaessige betydning i Danmark" Copenhagen.

Snorrason, E. (1950). "Polyarthritis chronica primaria". Thesis, (ㅁ

Copenhagen.
(1951). Acta med. scand., 140, 355.

Steinbrocker, O. (1941). "Arthritis in Modern Practice". Saund Philadelphia.

\section{Morbidité de l'arthrite rhumatismale}

RÉSUMÉ

On estime que la morbidité de l'arthrite rhumatismaleฏ s'élève à 0,8 pour mille, c'est à dire que sur les 4.500 .000 ⿸尸 habitants du Danemark cette maladie en frappe 3 à 40 mille tous les ans.

Pas tous les cas sont évolutifs, impliquant l'hospitalisation et le sécours social (pension d'infirmité). Il y en achez qui la lésion semble se limiter spontanément. On ne peut pas encore présenter le chiffre exact de tels cas, mais on espère l'obtenir en suivant les malades externeso mencionnés ici (malades de Valdemarsgade). Pour celaō on anticipe le ré-examen au bout de 5 ans des 124 caso reconnus au début.

\section{Morbidez de la artritis reumatoide SUMARIO}

La morbidez de la artritis reumatoide puede estimarse á cerca de 0,8 por mil, lo que quiere decir que 3 a 4 mip de los 4.500.000 habitantes de Dinamarca contraen esta enfermedad cada año.

No todos los casos son progresivos, necesitandó hospitalización y ayuda social (pensión de invalidez) En algunos la lesión parece limitarse espontáneamente No se puede todavía presentar la cifra exacta de tales casos, pero se espera obtenerla después de seguir a lose enfermos ambulatorios mencionados aquí (enfermos de Valdemarsgade). Con este objeto se anticipa el examer ulterior a cabo de 5 años de los 124 casos reconocidos temprano. 